Article

\title{
The Poisoning of $\mathrm{V}_{2} \mathrm{O}_{5}-\mathrm{WO}_{3} / \mathrm{TiO}_{2}$ and $\mathrm{V}_{2} \mathrm{O}_{5}-\mathrm{Ce}\left(\mathrm{SO}_{4}\right)_{2} / \mathrm{TiO}_{2} \mathrm{SCR}$ Catalysts by $\mathrm{KCl}$ and The Partial Regeneration by $\mathrm{SO}_{2}$
}

\author{
Hua Nie ${ }^{1,2}$, Wei $\mathrm{Li}^{1}$, Qirong $\mathrm{Wu}^{2}$, Vladislav Rac ${ }^{3}{ }^{\circledR}$, Vesna Rakić ${ }^{3}$ and Xuesen Du ${ }^{1, *}$ \\ 1 Key Laboratory of Low-Grade Energy Utilization Technologies and Systems, Ministry of Education of \\ People's Republic of China, Chongqing University, Chongqing 400044, China; niehua@spic.com.cn (H.N.); \\ weili19@cqu.edu.cn (W.L.) \\ 2 State Power Investment Corporation Yuanda Environmental Protection Engineering Co., Ltd., \\ Yancheng 224000, China; wqr20021@126.com \\ 3 Faculty of Agriculture, University of Belgrade, Nemanjina 6, 11080 Zemun-Belgrade, Serbia; \\ vladarac@agrif.bg.ac.rs (V.R.); vesna.rakic@agrif.bg.ac.rs (V.R.) \\ * Correspondence: xuesendu@cqu.edu.cn; Tel.: +86-23-6510-3101
}

Received: 19 November 2019; Accepted: 6 February 2020; Published: 8 February 2020

\begin{abstract}
Poisoning effects by alkali metal chlorides is one of the major reasons for the deactivation of SCR catalyst in biomass-fired plants. In this study, the influence of $\mathrm{KCl}$ on two vanadium-based catalysts with different promoters, $\mathrm{V}_{2} \mathrm{O}_{5}-\mathrm{WO}_{3} / \mathrm{TiO}_{2}$ and $\mathrm{V}_{2} \mathrm{O}_{5}-\mathrm{Ce}\left(\mathrm{SO}_{4}\right)_{2} / \mathrm{TiO}_{2}$, was investigated. The catalytic activity of the fresh $\mathrm{V}_{2} \mathrm{O}_{5}-\mathrm{WO}_{3} / \mathrm{TiO}_{2}$ was higher than that of $\mathrm{V}_{2} \mathrm{O}_{5}-\mathrm{Ce}\left(\mathrm{SO}_{4}\right)_{2} / \mathrm{TiO}_{2}$ at low temperatures. $\mathrm{V}_{2} \mathrm{O}_{5}-\mathrm{Ce}\left(\mathrm{SO}_{4}\right)_{2} / \mathrm{TiO}_{2}$ performed better than $\mathrm{V}_{2} \mathrm{O}_{5}-\mathrm{WO}_{3} / \mathrm{TiO}_{2}$ when $\mathrm{KCl}$ was deposited on the catalyst surface. Both poisoned catalysts were efficiently regenerated by $\mathrm{SO}_{2}$ treatment. The characterization results show that the reducibility and acidity of the catalysts were weakened by $\mathrm{KCl}$ deposition but regenerated by $\mathrm{SO}_{2}$.
\end{abstract}

Keywords: alkali-poisoning; $\mathrm{KCl} ; \mathrm{NH}_{3}-\mathrm{SCR} ; \mathrm{SO}_{2}$ regeneration

\section{Introduction}

$\mathrm{NO}_{x}$ from exhaust emissions is an important precursor of pollution sources such as smog and acid rain, causing severe damages to the natural environment. Selective catalytic reduction (SCR), with high efficiency of $\mathrm{NO}_{x}$ removal, is a wide-spread technology for reducing the emissions of $\mathrm{NO}_{x}$ from the flue gas of power plants and the exhaust gas of vehicles [1-4]. $\mathrm{NO}_{x}$ is reduced into harmless $\mathrm{N}_{2}$ by $\mathrm{NH}_{3}$ over catalysts, following Reactions (1)-(3) with different $\mathrm{NO} / \mathrm{NO}_{2}$ ratios [3,5-7]:

Standard-SCR:

$$
4 \mathrm{NO}+4 \mathrm{NH}_{3}+\mathrm{O}_{2} \rightarrow 4 \mathrm{~N}_{2}+6 \mathrm{H}_{2} \mathrm{O}
$$

Fast-SCR:

$$
\mathrm{NO}+\mathrm{NO}_{2}+2 \mathrm{NH}_{3} \rightarrow 2 \mathrm{~N}_{2}+3 \mathrm{H}_{2} \mathrm{O}
$$

$\mathrm{NO}_{2}-\mathrm{SCR}$ :

$$
6 \mathrm{NO}_{2}+8 \mathrm{NH}_{3} \rightarrow 7 \mathrm{~N}_{2}+12 \mathrm{H}_{2} \mathrm{O}
$$

Biomass has been used as a renewable fuel due to its environmentally-friendly features. However, the deactivation of the SCR catalyst used in the biomass-fired/cofired boilers is faster than that of coal-fired boilers [8]. The major difference between biomass and fossil fuels is the amount of alkali earth metals contained: it is higher in biofuels than in fossil fuels. Meanwhile, alkali earth metals are always contained in the flue gas and result in the deactivation of SCR [9]. 
The effect of alkali earth metals on catalysts, especially the commercial VWTi catalysts, has been investigated by many researchers. The activity of SCR catalysts gradually decreases as a result of the alkali accumulation on the catalyst [10]. The acidity of $\mathrm{V}_{2} \mathrm{O}_{5}-\mathrm{WO}_{3} / \mathrm{TiO}_{2}$ is affected by alkali earth metals owing to the reduction in the concentration of $\mathrm{V}-\mathrm{OH}$ Brønsted acid sites and the reducibility of active $\mathrm{V}^{5+}$ sites, which play a crucial role for the SCR reaction [11-13]. The effect of alkali metals on vanadium active sites has also been confirmed by DFT calculations [11]. $\mathrm{V}_{2} \mathrm{O}_{5}-\mathrm{WO}_{3} / \mathrm{TiO}_{2}$ is deactivated more seriously by $\mathrm{K}$ than $\mathrm{Ca}$ and $\mathrm{Mg}$ due to the greater decrease in the amount and stability of Brønsted acid sites [14]. The deactivation degree of $\mathrm{V}_{2} \mathrm{O}_{5}-\mathrm{WO}_{3} / \mathrm{TiO}_{2}$ caused by different forms of calcium follows the order: $\mathrm{CaCO}_{3}>\mathrm{CaO}>\mathrm{CaSO}_{4}$. $\mathrm{SO}_{4}{ }^{2-}$ can partly mitigate the $\mathrm{CaO}$ deactivation effect on acid sites [15]. A general method to enhance the alkali-resistance is to deposit promoters on the catalyst surface, which can increase the number of surface acid sites and strengthen their stability, thus improving the alkali metal resistance of commercial SCR catalysts [16]. Cerium, one of the promoters, is proved to enhance $\mathrm{V}_{2} \mathrm{O}_{5} / \mathrm{TiO}_{2} \mathrm{NO}_{\mathrm{x}}$ conversion [17].

Great efforts have been focused on the regeneration of poisoned catalysts and many methods were proposed $[18,19]$, such as water-washing and $\mathrm{SO}_{2}$-treatment. $\mathrm{SO}_{2}$ usually appears in the flue gas and leads to $\mathrm{SCR}$ catalysts deactivation. $\mathrm{NH}_{4} \mathrm{HSO}_{4}$ is deposited on the surface through the reaction among $\mathrm{SO}_{2}, \mathrm{H}_{2} \mathrm{O}$, and $\mathrm{NH}_{3}$, plugging the catalyst pores at low temperatures [20-22]. Ce-based oxide catalytic activity can be significantly enhanced through $\mathrm{SO}_{2}$-treatment, and the surface acidity of catalyst is strengthened through impregnation with $\mathrm{H}_{2} \mathrm{SO}_{4}$ solution [22,23]. It is of great interest to study the regeneration of alkali metals-poisoned catalysts through $\mathrm{SO}_{2}$ treatment.

The impact of $\mathrm{KCl}$ on the $\mathrm{V}_{2} \mathrm{O}_{5}-\mathrm{WO}_{3} / \mathrm{TiO}_{2}$ and $\mathrm{V}_{2} \mathrm{O}_{5}-\mathrm{Ce}\left(\mathrm{SO}_{4}\right)_{2} / \mathrm{TiO}_{2}$ catalysts (denoted as VWTi and VCeTi, respectively) was studied. The catalyst poisoning in stationary $\mathrm{NO}_{\mathrm{x}}$ sources applications (biomass fired/cofired boilers) was simulated. Experiments were conducted to investigate the regeneration of the poisoned catalysts through $\mathrm{SO}_{2}$ treatment. The fresh, poisoned, and regenerated catalyst samples were characterized by $\mathrm{H}_{2}$-TPR and $\mathrm{NH}_{3}$-TPD experiments. The catalytic activity of the fresh VWTi was higher than that of VCeTi at low temperature, while VCeTi performed better than VWTi when $\mathrm{KCl}$ was deposited on the catalyst. $\mathrm{SO}_{2}$-treatment could efficiently regenerate the poisoned catalysts, especially the VCeTi catalyst.

\section{Results and Discussion}

\subsection{Poisoning Effect of $\mathrm{KCl}$ on VWTi Catalyst}

Figure 1 illustrates the performance of the VWTi catalyst with different $\mathrm{KCl}$ deposition contents under different calcination temperatures. The catalytic activity of VWTi catalysts decreased with increasing of the molar ratio of $\mathrm{n}(\mathrm{K}) / \mathrm{n}(\mathrm{V})$ (i.e., the molar ratio of $\mathrm{KCl}$ and $\left.\mathrm{V}_{2} \mathrm{O}_{5}\right)$, although the calcination temperature $\left(\mathrm{T}_{\text {calc }}\right)$ was different $\left(\mathrm{T}_{\text {calc }}=320\right.$ and $370{ }^{\circ} \mathrm{C} ; \mathrm{T}_{\text {calc }}$ was $20^{\circ} \mathrm{C}$ higher than the highest test temperature). Obviously, the catalytic activity decreased significantly owing to the $\mathrm{KCl}$ deposition. It indicates that VWTi is susceptible to the alkali species as $\mathrm{KCl}$; especially when the molar ratio of $\mathrm{n}(\mathrm{K}) / \mathrm{n}(\mathrm{V})$ is 1.5 , the NO conversion decreased by more than $50 \%$. The results are consistent with the poisoning phenomenon that occur during the operation of a biomass power plant: the catalytic activity decreases due to the deposition and accumulation of $\mathrm{KCl}$. The alkali metal ions $\left(\mathrm{K}^{+}\right)$evaporated from the fuel will absorb on the catalysts surface and form solid $\mathrm{KCl}$ particles on the catalyst surface [9]. Moreover, a parallel tendency of the VWTi catalysts calcinated at 345,395 , and $420{ }^{\circ} \mathrm{C}$ was obtained and $\mathrm{N}_{2}$-selectivity ( $>95 \%$ ) of VWTi catalysts was barely affected by $\mathrm{KCl}$. Figure 2 depicts the NO conversion of poisoned VWTi with different $\mathrm{T}_{\text {calc. }}$. Fluctuations were clearly observed with different $\mathrm{T}_{\text {calc, }}$, while all the VWTi catalysts activities dropped due to $\mathrm{KCl}$ deposition. The highest point of NO conversion can be explained by the fact that $\mathrm{NO}$ conversion of fresh VWTi peaked at $370{ }^{\circ} \mathrm{C}$. The reason for the decrease of $\mathrm{NO}$ conversion at $345^{\circ} \mathrm{C}$ is that diffusion of small $\mathrm{KCl}$ clusters on the catalyst surface led to increasing interface per unit mass of $\mathrm{KCl}$, which is equivalent to the covering of likely active catalytic sites [24-26]. The decreased degree of $\mathrm{NO}$ conversion at $345^{\circ} \mathrm{C}$ was weakened obviously at 
elevated $\mathrm{n}(\mathrm{K}) / \mathrm{n}(\mathrm{V})$. Therefore, the two effects, of alkali metal and the NO conversion fluctuations of fresh catalysts, together led to the results demonstrated in Figure 2.
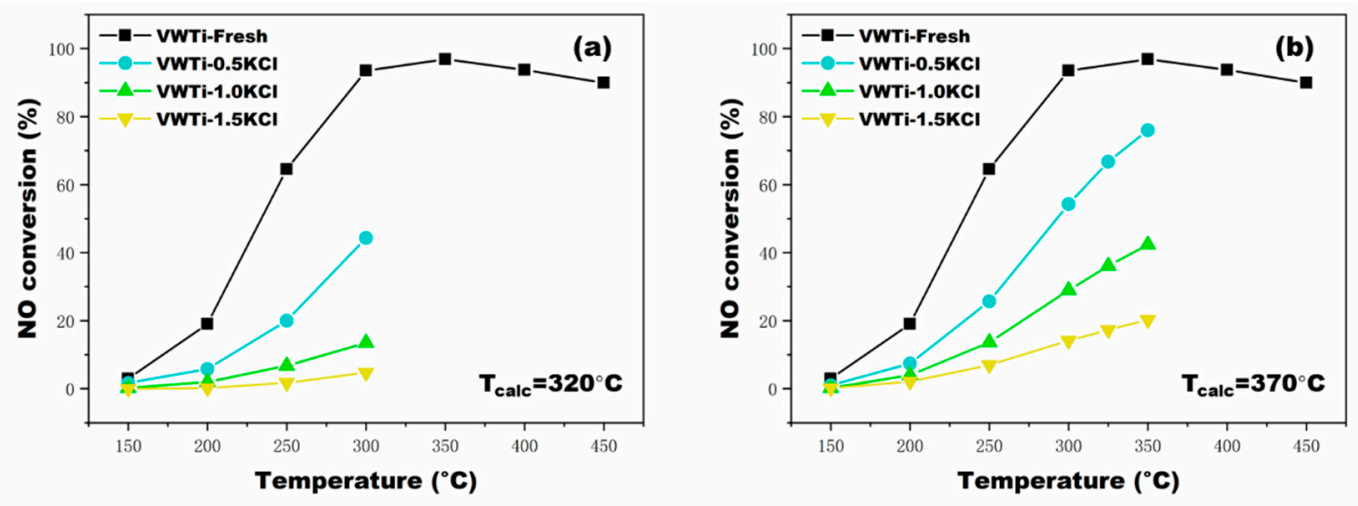

Figure 1. Effects of three $\mathrm{n}(\mathrm{K}) / \mathrm{n}(\mathrm{V})$ ratios on activity of $\mathrm{V}_{2} \mathrm{O}_{5}-\mathrm{WO}_{3} / \mathrm{TiO}_{2}$ catalyst calcinated at: (a) $320^{\circ} \mathrm{C}$; and (b) $370{ }^{\circ} \mathrm{C}$.

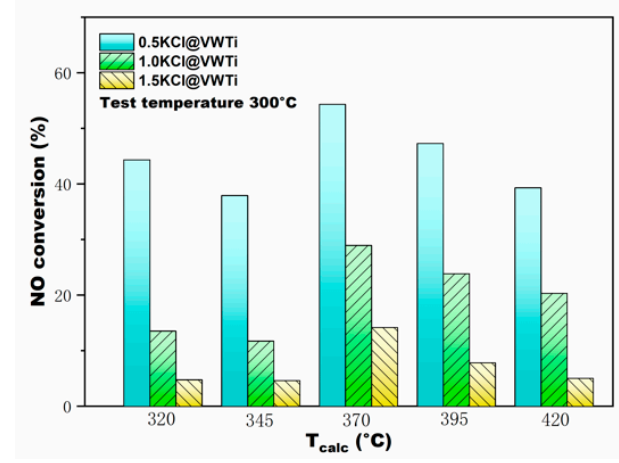

Figure 2. NO conversion of three $\mathrm{n}(\mathrm{K}) / \mathrm{n}(\mathrm{V})$ of $\mathrm{KCl}$ poisoned $\mathrm{V}_{2} \mathrm{O}_{5}-\mathrm{WO}_{3} / \mathrm{TiO}_{2}$ catalysts at different $\mathrm{T}_{\text {calc }}$. The test temperature was $300^{\circ} \mathrm{C}$.

\subsection{Comparison of Alkali Resistance of VCeTi and VWTi Catalysts}

Figure 3 shows the influence of different $T_{\text {calc }}$ and molar ratios of $n(K) / n(V)$ on the $\mathrm{V}_{2} \mathrm{O}_{5}-\mathrm{Ce}\left(\mathrm{SO}_{4}\right)_{2} / \mathrm{TiO}_{2}$. As illustrated in these figures, the fresh $\mathrm{V}_{2} \mathrm{O}_{5}-\mathrm{WO}_{3} / \mathrm{TiO}_{2}$ performed better than the fresh $\mathrm{V}_{2} \mathrm{O}_{5}-\mathrm{Ce}\left(\mathrm{SO}_{4}\right)_{2} / \mathrm{TiO}_{2}$ at low temperature in terms of activity, whereas their activities were approximately equal at high temperature. Moreover, the $\mathrm{NO}$ conversion of all catalysts decreased due to $\mathrm{KCl}$ loading. Higher alkali loading imposed a stronger poisoning influence on both VWTi and VCeTi catalysts. One exception is that the VCeTi catalyst was slightly more strongly deactivated when the deposition ratio was 1.0, rather than 1.5 , at the calcination temperature of $320^{\circ} \mathrm{C}$. VWTi was sensitive to alkali metal such as potassium, as discussed in Section 2.1, while VCeTi possessed a better alkali resistance than VWTi. It in demonstrated in Figure 3 that the VCeTi exhibited a superior NO conversion than VWTi after poisoning at the test temperature; the explanation for this might be the superior oxidation properties of $\mathrm{Ce}^{4+}$ and acidity of $\mathrm{SO}_{4}{ }^{2-}$ [23]. The same experiments were also conducted on poisoned VWTi and VCeTi calcinated at 345,395 and $420{ }^{\circ} \mathrm{C}$, respectively, and the results are consistent with those discussed above. Figure 4 demonstrates a comparison of poisoned VCeTi calcinated at different temperatures. It can be noticed that the poisoned VCeTi catalytic activity decreased slightly with $\mathrm{T}_{\text {calc }}$ changing. What is more interesting is that activities of VCeTi catalysts barely changed at $n(K) / n(V)=1.0,1.5$. Based on the experimental results, it can be concluded that VCeTi catalysts possess superior alkaline resistance in a wide calcination temperature window. 

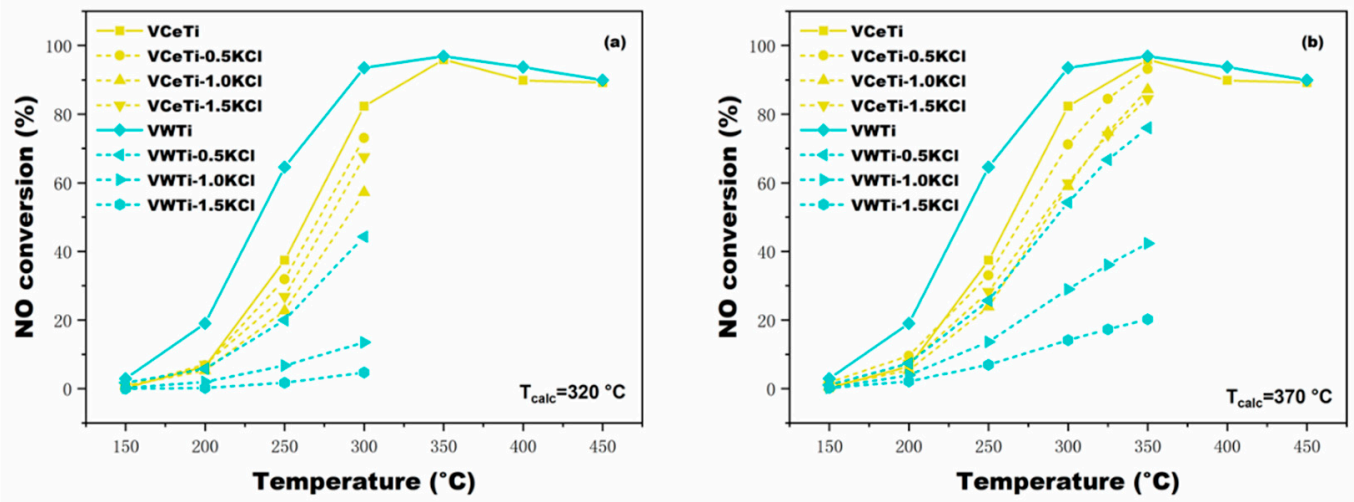

Figure 3. Comparison of activities between $\mathrm{V}_{2} \mathrm{O}_{5}-\mathrm{WO}_{3} / \mathrm{TiO}_{2}$ and $\mathrm{V}_{2} \mathrm{O}_{5}-\mathrm{Ce}\left(\mathrm{SO}_{4}\right)_{2} / \mathrm{TiO}_{2}$ catalyst samples with $\mathrm{KCl}$ deposition at different $\mathrm{T}_{\text {calc }}$ : (a) $320^{\circ} \mathrm{C}$; and (b) $370{ }^{\circ} \mathrm{C}$.

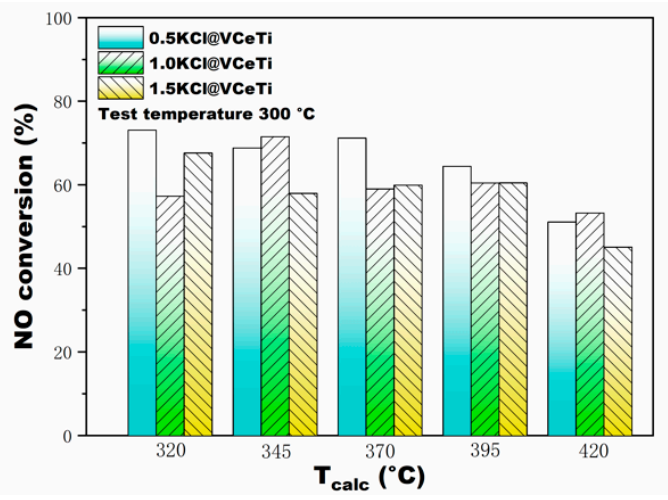

Figure 4. $\mathrm{NO}$ conversion of three $\mathrm{n}(\mathrm{K}) / \mathrm{n}(\mathrm{V})$ of $\mathrm{KCl}$ poisoned $\mathrm{V}_{2} \mathrm{O}_{5}-\mathrm{Ce}\left(\mathrm{SO}_{4}\right)_{2} / \mathrm{TiO}_{2}$ catalyst at different $\mathrm{T}_{\text {calc. }}$ The test temperature was $300^{\circ} \mathrm{C}$.

\subsection{The Regeneration of the Poisoned Catalysts}

The regeneration of poisoned catalysts has been investigated by many researchers, and many effective methods have been proposed [27-30]. $\mathrm{SO}_{2}$ is always contained in the flue gas $[27,28]$. Consequently, experiments were conducted to explore the regeneration of poisoned catalysts by $\mathrm{SO}_{2}$ treatment. Figure $5 \mathrm{a}$ indicates that the catalytic activity of poisoned VWTi catalysts was dramatically enhanced after $\mathrm{SO}_{2}$ treatment, even though the activity was still slightly lower than the fresh catalyst. The catalytic activity of regenerated catalysts peaked at $\mathrm{T}_{\text {calc }}=370^{\circ} \mathrm{C}$, and then decreased at elevated temperature. The regeneration of poisoned VWTi catalysts with 0.5 and $1.0 \mathrm{n}(\mathrm{K}) / \mathrm{n}(\mathrm{V})$ molar ratios was also investigated. The catalysts with the low molar ratio of $n(K) / n(V)$ possessed a higher NO conversion than the catalysts with the high molar ratio of $n(K) / n(V)$ after regeneration. This observation validates that the deactivation arose from $\mathrm{KCl}$ and can be regenerated to some extent.

The $\mathrm{SO}_{2}$ treatment on poisoned VCeTi catalysts was also employed, and experimental results are plotted in Figure $5 \mathrm{~b}$. The activity of poisoned VCeTi was promoted after $\mathrm{SO}_{2}$ treatment, and barely fluctuated after $\mathrm{T}_{\text {calc }}=320^{\circ} \mathrm{C}$. It is more interesting that the activity of the regenerated catalyst was even better than that of the fresh catalyst. The reasons for this are more Brønsted acid sites were formed from potassium sulfate and active sites emerged due to surface sulfation by $\mathrm{SO}_{2}$ [29]. As reported, the number of Brønsted acid sites increased because the surface sulfates on $\mathrm{TiO}_{2}$ were converted to bidentate surface species (acidic S-OH groups) [30-33], and the reaction rate increased as a result of more Brønsted acid sites [34]. 

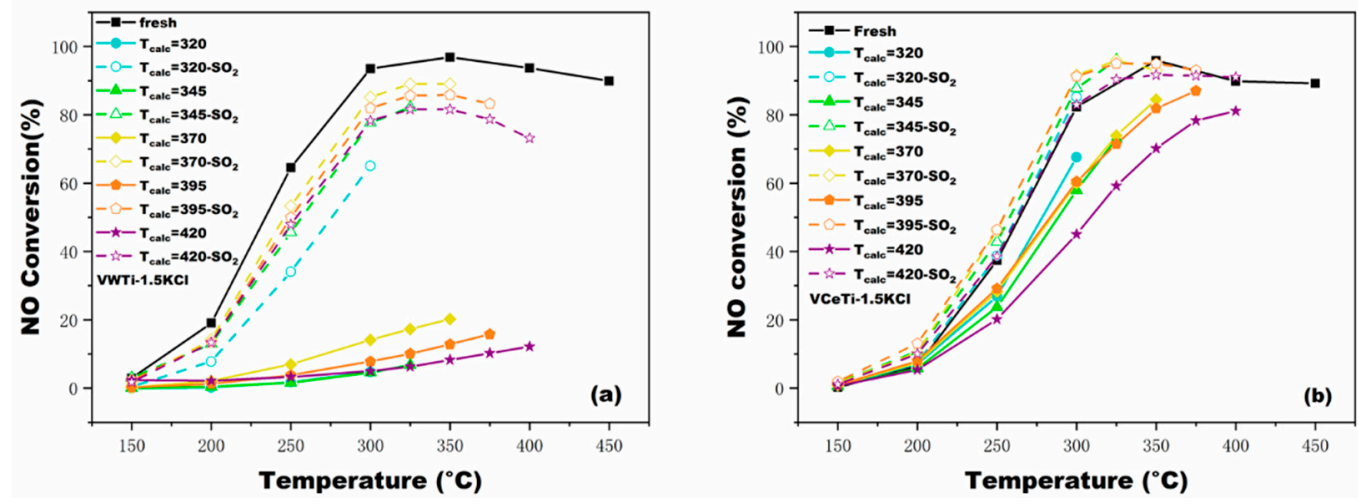

Figure 5. Regeneration effects of: (a) poisoned $\mathrm{V}_{2} \mathrm{O}_{5}-\mathrm{WO}_{3} / \mathrm{TiO}_{2}$ catalyst; and (b) poisoned $\mathrm{V}_{2} \mathrm{O}_{5}-\mathrm{Ce}\left(\mathrm{SO}_{4}\right)_{2} / \mathrm{TiO}_{2}$ catalyst at $\mathrm{n}(\mathrm{K}) / \mathrm{n}(\mathrm{V})=1.5$ through $\mathrm{SO}_{2}$-treatment. The poisoned catalysts were calcinated at $320,345,370,395$, and $420^{\circ} \mathrm{C}$, and the temperature for $\mathrm{SO}_{2}$-treatment corresponded with calcination temperature.

\subsection{Surface Acidity and Redox Properties}

$\mathrm{NH}_{3}$-TPD experiments were employed to investigate the amount and strength of the acid sites on the fresh, poisoned, and regenerated catalysts. The peaks at low $\left(<300^{\circ} \mathrm{C}\right)$ and high $\left(>300^{\circ} \mathrm{C}\right)$ temperature are regarded as weakly chemisorbed $\mathrm{NH}_{3}$ and strongly chemisorbed $\mathrm{NH}_{3}$, respectively [35]. Figure 6a shows the curves of $\mathrm{NH}_{3}$ desorption peak over VWTi catalysts. For poisoned catalyst, the intensity of the $\mathrm{NH}_{3}$ desorption dramatically decreased at both low and high temperature; especially, the number of strong acids was reduced by $88 \%$ according to the integral value of peak area (from 10,374 to 1229) at high temperature. The results are in agreement with those in Reference [36]. Our previous works proposed that 1 V5WTi catalyst covers all exposed $\mathrm{TiO}_{2}$ surface sites [6,37]; both Lewis acid and Brønsted acid sites exist on the VWTi catalyst [38]. Both are also reduced by $\mathrm{KCl}$ and result in deactivation, while the number of weak acid sites was extremely enhanced (integral value of the peak area from 3318 to 11,984 ) through $\mathrm{SO}_{2}$-treatment, which certified the regeneration by $\mathrm{SO}_{2}$-treatment. However, the adsorption capacity of a strong acid was nearly the same (integral value of peak area from 1229 to 1255) after regeneration. Based on $\mathrm{NH}_{3}$-TPD results (Figure 6a) and the $\mathrm{NO}$ conversion of fresh, poisoned, and regenerated VWTi catalysts (Figure 5a), it is logical that the NO conversion responsed to the surface acidity variation. Figure $6 \mathrm{~b}$ demonstrates the $\mathrm{NH}_{3}$-TPD results of VCeTi catalysts. As for the poisoned VCeTi catalyst, the intensity of the TPD peak dropped slightly, whereas the peak position did not change. After $\mathrm{SO}_{2}$-treatment, the intensity of weak acid sites improved moderately at low temperatures; however, the intensity of strong acid sites still decreased. This observation suggests that the VCeTi catalytic activity was dominated by Brønsted acid, and the increased Brønsted acid sites strengthened catalytic activity through regeneration $[39,40]$. The gap of regeneration degree between the poisoned VWTi and VCeTi catalyst can be explained by the fact that the room for surface acidity improved. Since poisoned VCeTi catalyst exhibited a superior surface acidity to poisoned VWTi, the acidity improvement room for poisoned VCeTi was smaller than that of poisoned VWTi (after deposition of $\mathrm{KCl}$, the integral value of $\mathrm{NH}_{3}$ desorption peak area decreased from 20,245 to 4547 for VWTi, while from 21,862 to 13,912 for VCeTi). Therefore, the regeneration of poisoned VCeTi catalysts by $\mathrm{SO}_{2}$-treatment is not obvious.

The $\mathrm{H}_{2}$ consumption of fresh and poisoned catalysts was obtained through $\mathrm{H}_{2}$-TPR experiments. As shown in Figure 7a, VWTi catalyst exhibited two TPR peaks: TPR Peak (1) at low temperatures shifted towards high temperatures with the deposition of $\mathrm{KCl}$, whereas TPR Peak (2) at high temperatures did not change. Peak (1) was assigned to the reduction of $\mathrm{V}^{5+}$ to $\mathrm{V}^{3+}$ and $\mathrm{W}^{6+}$ to $\mathrm{W}^{4+}$ [41], which revealed that the redox ability of $\mathrm{V}$ and $\mathrm{W}$ was decreased after deposition of $\mathrm{KCl}$, consistent with the activity results. Peak (2) belongs to the reduction of $\mathrm{W}^{4+}$ to $\mathrm{W}^{0}$ [42]. The $\mathrm{H}_{2}$ consumption peak of fresh VCeTi catalyst contained two overlapped reduction peaks, which can be assigned to $\mathrm{V}^{5+}$ and $\mathrm{Ce}^{4+}$, 
respectively, and a synergistic effect between $\mathrm{Ce}^{4+}$ and $\mathrm{V}^{5+}$ appeared due to the adjacent peak positions. Through the deposition of $\mathrm{KCl}$, a deviation of the TPR reduction peak was observed, the former peak being related to the reduction of $\mathrm{V}^{5+}$ to $\mathrm{V}^{3+}$, while the latter being assigned to the reduction of $\mathrm{Ce}^{4+}$ to $\mathrm{Ce}^{3+}[17,43,44]$. It is reported that oxygen vacancies are yielded with the conversion of $\mathrm{Ce}^{4+}$ to $\mathrm{Ce}^{3+}[45]$. Oxygen vacancies are beneficial to catalytic activity, thus making VCeTi catalysts perform better than VWTi.
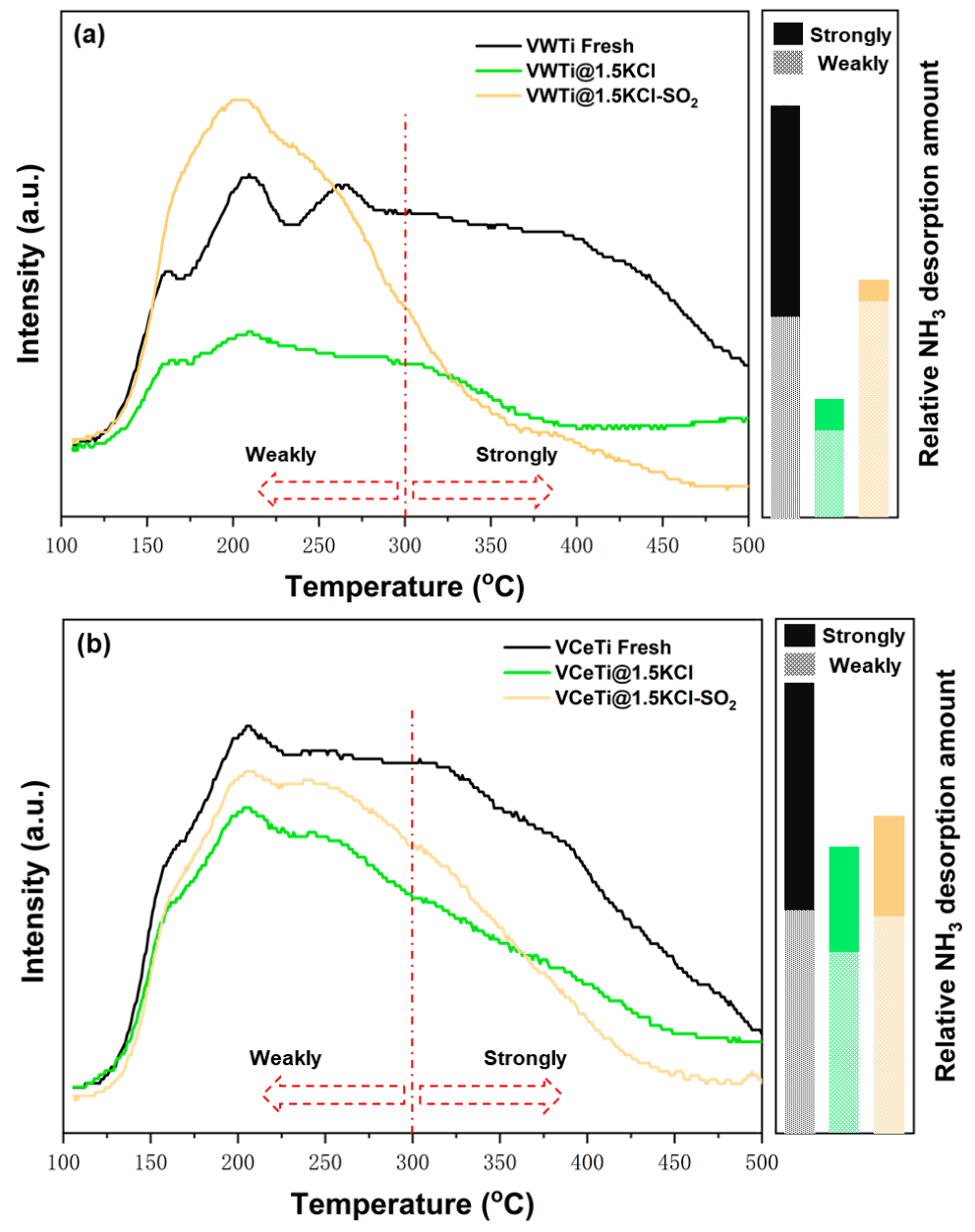

Figure 6. $\mathrm{NH}_{3}-\mathrm{TPD}$ profiles of the fresh poisoned and regenerated: (a) $\mathrm{V}_{2} \mathrm{O}_{5}-\mathrm{WO}_{3} / \mathrm{TiO}_{2}$ catalyst; and (b) $\mathrm{V}_{2} \mathrm{O}_{5}-\mathrm{Ce}\left(\mathrm{SO}_{4}\right)_{2} / \mathrm{TiO}_{2}$ catalyst.
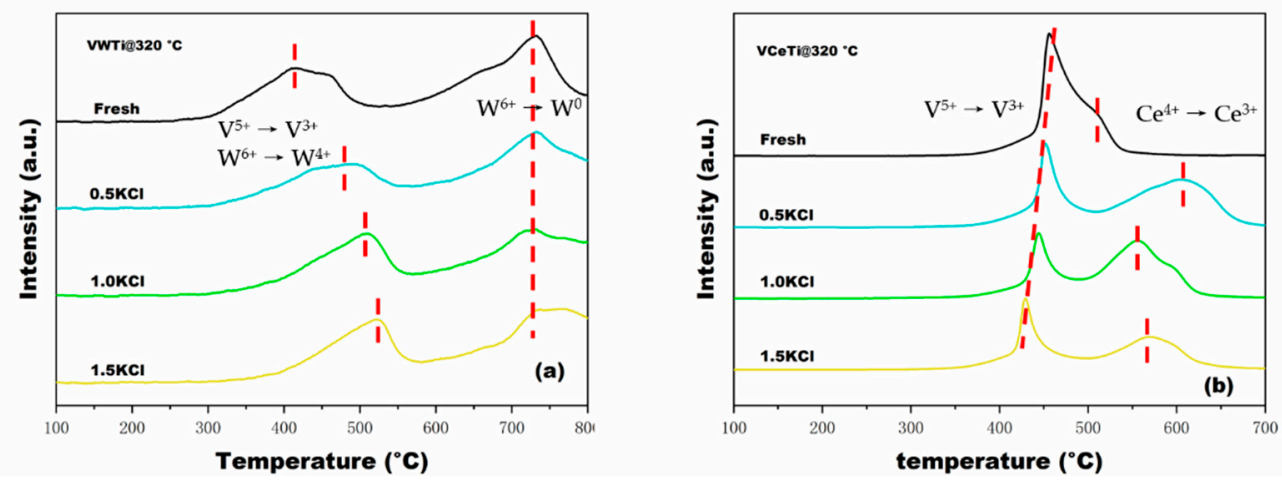

Figure 7. $\mathrm{H}_{2}-\mathrm{TPR}$ profiles of catalysts at three $\mathrm{n}(\mathrm{K}) / \mathrm{n}(\mathrm{V})$ ratios: (a) $\mathrm{V}_{2} \mathrm{O}_{5}-\mathrm{WO}_{3} / \mathrm{TiO}_{2}$; and (b) $\mathrm{V}_{2} \mathrm{O}_{5}-\mathrm{Ce}\left(\mathrm{SO}_{4}\right)_{2} / \mathrm{TiO}_{2}$. 


\section{Materials and Methods}

\subsection{Catalyst Synthesis}

1 wt. $\% \mathrm{~V}_{2} \mathrm{O}_{5}-5$ wt. $\% \mathrm{WO}_{3} / \mathrm{TiO}_{2}$ and 1 wt. $\% \mathrm{~V}_{2} \mathrm{O}_{5}-11.74$ wt. $\% \mathrm{Ce}\left(\mathrm{SO}_{4}\right)_{2} / \mathrm{TiO}_{2}\left(11.74\right.$ wt. $\% \mathrm{Ce}\left(\mathrm{SO}_{4}\right)_{2}$ was calculated according to $\left.5 \mathrm{wt} . \% \mathrm{CeO}_{2}\right)$ were synthesized by the impregnation method. Ammonium vanadate $\left(\mathrm{NH}_{4} \mathrm{VO}_{3}\right.$ Aladdin, $\left.\mathrm{AP}\right)$ and ammonium metatungnate $\left(\left(\mathrm{NH}_{4}\right)_{6} \mathrm{H}_{2} \mathrm{~W}_{12} \mathrm{O}_{40} \cdot x \mathrm{H}_{2} \mathrm{O}\right.$ Aladdin, $\left.\mathrm{AP}\right)$, used as the precursors of $\mathrm{V}_{2} \mathrm{O}_{5}$ and $\mathrm{WO}_{3}$, respectively, were dissolved in deionized water, acidified by oxalic acid, and then vigorously stirred at $60{ }^{\circ} \mathrm{C}$ for $30 \mathrm{~min}$. After impregnation of $\mathrm{V}$ - and $\mathrm{W}$-precursor on $\mathrm{TiO}_{2}$ (Degussa, P25, $\mathrm{S}_{\mathrm{BET}}=55 \mathrm{~m}^{2} / \mathrm{g}$ ) in a desired proportion, the synthesized samples were dried at $120{ }^{\circ} \mathrm{C}$ for $12 \mathrm{~h}$, and subsequently calcinated at $500{ }^{\circ} \mathrm{C}$ for $5 \mathrm{~h} . \mathrm{V}_{2} \mathrm{O}_{5}-\mathrm{Ce}\left(\mathrm{SO}_{4}\right)_{2} / \mathrm{TiO}_{2}$ was prepared by the same method. Ceric sulfate $\left(\mathrm{Ce}\left(\mathrm{SO}_{4}\right)_{2} \cdot 4 \mathrm{H}_{2} \mathrm{O}\right.$ Aladdin $\left.\mathrm{AP}\right)$ was the precursor of $\mathrm{Ce}\left(\mathrm{SO}_{4}\right)_{2}$. The detailed synthesis procedure is described in our previous work [46]. The poisoned catalyst was synthesized by impregnation. Potassium chloride $(\mathrm{KCl}, \mathrm{AP})$, the alkaline reactant, was dissolved in deionized water and sufficiently stirred, and then mixed with the prepared powdery catalyst according to the molar ratios of $\mathrm{n}(\mathrm{K}) / \mathrm{n}(\mathrm{V})=0.5,1.0$ and 1.5 . The catalyst was subsequently dried and then calcinated at 320 , $345,370,395$ and $420^{\circ} \mathrm{C}$ to simulate the varying poisoning situations that occur in biomass-fired plants under different operating temperatures.

\subsection{Catalytic Performance}

The $\mathrm{NH}_{3}$-SCR reactivity tests were completed on a quartz tube where the catalyst was placed in, and the feed gas of selected composition went through the tube. Meanwhile, the tube was heated by electric furnace. A thermocouple was injected to the bed of the catalyst to monitor the temperature, which was recorded and used in this paper. The feed gas contained $500 \mathrm{ppm} \mathrm{NH}_{3}, 500 \mathrm{ppm} \mathrm{NO}$, and $5 \mathrm{vol} \% \mathrm{O}_{2}$ with $\mathrm{N}_{2}$ as the balance gas. A catalyst sample of $0.5 \mathrm{~g}$ with the particle size of 40-60 mesh was used, and the gas hourly space velocity (GHSV) for all experiments was $150,000 \mathrm{~mL} \cdot \mathrm{g}^{-1} \cdot \mathrm{h}^{-1}$. The gas compositions were measured by Protea ProtIR 204M online flue gas analyzer. The value of NO conversion was calculated as follows:

$$
\text { NO conversion }(\%)=\frac{[\mathrm{NO}]_{\text {in }}-[\mathrm{NO}]_{\text {out }}}{[\mathrm{NO}]_{\text {in }}} \times 100
$$

\subsection{Regeneration Methods}

The poisoned catalysts were treated in a quartz tube with a stream of $1000 \mathrm{~mL} / \mathrm{min}$ mixed gas contained 500 ppm SO 2,5 vol $\% \mathrm{O}_{2}$ and $\mathrm{N}_{2}$ as the carrier, under different temperatures $(320,345,370$, 395 and $420^{\circ} \mathrm{C}$, according to the $\mathrm{T}_{\text {calc }}$ ) for $1 \mathrm{~h}$.

\subsection{Catalyst Characterization}

A PX200A equipment was employed for $\mathrm{NH}_{3}$ temperature-programmed desorption of ammonia $\left(\mathrm{NH}_{3}\right.$-TPD). Powder catalyst $(0.2 \mathrm{~g})$ was purged in an atmosphere of $50 \mathrm{~mL} / \mathrm{min}$ He while the temperature was heated up to $400{ }^{\circ} \mathrm{C}$ at $10{ }^{\circ} \mathrm{C} / \mathrm{min}$. The purging time was $10 \mathrm{~min}$; then, the sample was cooled gradually down to $100{ }^{\circ} \mathrm{C}$ and saturated with $50 \mathrm{~mL} / \mathrm{min} \mathrm{NH}_{3}$ and $50 \mathrm{~mL} / \mathrm{min} \mathrm{He}$ for $30 \mathrm{~min}$. After saturation, the sample was purged with pure He at $50 \mathrm{~mL} / \mathrm{min}$ until the thermal conductivity detector (TCD) signal was stabilized. The signal was collected while the temperature was raised to $500{ }^{\circ} \mathrm{C}$ (slope of $10^{\circ} \mathrm{C} / \mathrm{min}$ ).

$\mathrm{H}_{2}$-temperature programmed reduction $\left(\mathrm{H}_{2}\right.$-TPR) was conducted using the PX200A instrument. The catalyst $(0.2 \mathrm{~g})$ was purged with pure $\mathrm{He}$ at $200{ }^{\circ} \mathrm{C}$ for $30 \mathrm{~min}$, and then $\mathrm{H}_{2} /$ Ar mixture gas $(10 \mathrm{vol} \%$ $\mathrm{H}_{2}$ ) was pumped into the reactor with a rate of $50 \mathrm{~mL} / \mathrm{min}$. Thirty minutes later, the sample was cooled to ambient temperature in pure He and subsequently heated to $800{ }^{\circ} \mathrm{C}$ at a rate of $10{ }^{\circ} \mathrm{C} / \mathrm{min}$ under $10 \mathrm{vol} \% \mathrm{H}_{2} /$ Ar. The values of $\mathrm{H}_{2}$ consumption were obtained through TCD. 


\section{Conclusions}

This systematic experimental investigation focused on the effects of $\mathrm{KCl}$ and $\mathrm{SO}_{2}$ on $\mathrm{V}_{2} \mathrm{O}_{5}-\mathrm{WO}_{3} / \mathrm{TiO}_{2}$ and $\mathrm{V}_{2} \mathrm{O}_{5}-\mathrm{Ce}\left(\mathrm{SO}_{4}\right)_{2} / \mathrm{TiO}_{2} . \mathrm{V}_{2} \mathrm{O}_{5}-\mathrm{WO}_{3} / \mathrm{TiO}_{2}$ and $\mathrm{V}_{2} \mathrm{O}_{5}-\mathrm{Ce}\left(\mathrm{SO}_{4}\right)_{2} / \mathrm{TiO}_{2}$ were calcinated at different temperatures. Their catalytic activities were inhibited by $\mathrm{KCl}$ loading with different molar ratios. The characterization afterwards showed that the reducibility and acidity of $\mathrm{V}_{2} \mathrm{O}_{5}-\mathrm{WO}_{3} / \mathrm{TiO}_{2}$ and $\mathrm{V}_{2} \mathrm{O}_{5}-\mathrm{Ce}\left(\mathrm{SO}_{4}\right)_{2} / \mathrm{TiO}_{2}$ were remarkably decreased by $\mathrm{KCl} . \mathrm{V}_{2} \mathrm{O}_{5}-\mathrm{Ce}\left(\mathrm{SO}_{4}\right)_{2} / \mathrm{TiO}_{2}$ exhibited a superior alkali metal resistance to $\mathrm{V}_{2} \mathrm{O}_{5}-\mathrm{WO}_{3} / \mathrm{TiO}_{2}$; the poisoned catalytic activity can be efficiently regenerated through $\mathrm{SO}_{2}$ treatment. $\mathrm{V}_{2} \mathrm{O}_{5}-\mathrm{Ce}\left(\mathrm{SO}_{4}\right)_{2} / \mathrm{TiO}_{2}$ even possessed a better activity than the fresh catalyst.

Author Contributions: Conceptualization, H.N.; Formal analysis, V.R. (Vladislav Rac) and V.R. (Vesna Rakić); Funding acquisition, X.D.; Investigation, H.N. and Q.W.; Resources, X.D.; Supervision, X.D.; Writing - original draft, W.L.; Writing - review \& editing, X.D. All authors have read and agreed to the published version of the manuscript.

Funding: We gratefully acknowledge the financial support of National Natural Science Foundation of China (51506015), Chongqing Technology Innovation and Application Demonstration Projects (cstc2018jscx-msyb0999), Fundamental Research Funds for the Central Universities (2018CDQYDL0050 and 2018CDJDDL0004), and Open Fund of Key Laboratory of Low-grade Energy Utilization Technologies and Systems, Ministry of Education of China (LLEUTS-2019002).

Acknowledgments: This work was supported by National Natural Science Foundation of China (51506015), Chongqing Technology Innovation and Application Demonstration Projects (cstc2018jscX-msyb0999), Fundamental Research Funds for the Central Universities (2018CDQYDL0050 and 2018CDJDDL0004), and Open Fund of Key Laboratory of Low-grade Energy Utilization Technologies and Systems, Ministry of Education of China (LLEUTS-2019002).

Conflicts of Interest: The authors declare no conflict of interest.

\section{References}

1. Taylor, K.C. Nitric oxide catalysis in automotive exhaust systems. Catal. Rev. Sci. Eng. 1993, 35, 457-481. [CrossRef]

2. Busca, G.; Lietti, L.; Ramis, G.; Berti, F. Chemical and mechanistic aspects of the selective catalytic reduction of $\mathrm{NO}_{\mathrm{x}}$ by ammonia over oxide catalysts: A review. Appl. Catal. B Environ. 1998, 18, 1-36. [CrossRef]

3. Lai, J.-K.; Wachs, I.E. A Perspective on the Selective Catalytic Reduction (SCR) of NO with $\mathrm{NH}_{3}$ by Supported $\mathrm{V}_{2} \mathrm{O}_{5}-\mathrm{WO}_{3} / \mathrm{TiO}_{2}$ Catalysts. ACS Catal. 2018, 8, 6537-6551. [CrossRef]

4. Wang, X.; Du, X.; Xue, J.; Yang, G.; Chen, Y.; Zhang, L. New insights into the $\mathrm{N}_{2} \mathrm{O}$ formation mechanism during selective catalytic reduction of $\mathrm{NO}_{x}$ with $\mathrm{NH}_{3}$ over V-based catalyst. Catal. Today 2019. [CrossRef]

5. Grossale, A.; Nova, I.; Tronconi, E.; Chatterjee, D.; Weibel, M. $\mathrm{NH}_{3}-\mathrm{NO} / \mathrm{NO}_{2} \mathrm{SCR}$ for Diesel Exhausts Aftertreatment: Reactivity, Mechanism and Kinetic Modelling of Commercial Fe- and Cu-Promoted Zeolite Catalysts. Top. Catal. 2009, 52, 1837-1841. [CrossRef]

6. Wang, X.; Du, X.; Zhang, L.; Chen, Y.; Yang, G.; Ran, J. Promotion of $\mathrm{NH}_{4} \mathrm{HSO}_{4}$ decomposition in $\mathrm{NO} / \mathrm{NO}_{2}$ contained atmosphere at low temperature over $\mathrm{V}_{2} \mathrm{O}_{5}-\mathrm{WO}_{3} / \mathrm{TiO}_{2}$ catalyst for $\mathrm{NO}$ reduction. Appl. Catal. A Gen. 2018, 559, 112-121. [CrossRef]

7. Wang, X.; Du, X.; Liu, S.; Yang, G.; Chen, Y.; Zhang, L.; Tu, X. Understanding the deposition and reaction mechanism of ammonium bisulfate on a vanadia SCR catalyst: A combined DFT and experimental study. Appl. Catal. B Environ. 2020, 260, 118168. [CrossRef]

8. Khodayari, R.; Andersson, C.; Odenbrand, I.; Andersson, L.A. Deactivation and regeneration of SCR catalysts used in bio fuel power plants. In Proceedings of the 5th European Conference on Industrial Furnaces and Boilers, Porto, Portugal, 11-14 April 2000; pp. 543-554.

9. Zheng, Y.; Jensen, A.D.; Johnsson, J.E. Laboratory Investigation of Selective Catalytic Reduction Catalysts: Deactivation by Potassium Compounds and Catalyst Regeneration. Ind. Eng. Chem. Res. 2004, 43, 941-947. [CrossRef]

10. Kling, Å.; Andersson, C.; Myringer, Å.; Eskilsson, D.; Järås, S.G. Alkali deactivation of high-dust SCR catalysts used for $\mathrm{NO}_{\mathrm{x}}$ reduction exposed to flue gas from 100MW-scale biofuel and peat fired boilers: Influence of flue gas composition. Appl. Catal. B Environ. 2007, 69, 240-251. [CrossRef] 
11. Nicosia, D.; Czekaj, I.; Kröcher, O. Chemical deactivation of $\mathrm{V}_{2} \mathrm{O}_{5} / \mathrm{WO}_{3}-\mathrm{TiO}_{2} \mathrm{SCR}$ catalysts by additives and impurities from fuels, lubrication oils and urea solution: Part II. Characterization study of the effect of alkali and alkaline earth metals. Appl. Catal. B Environ. 2008, 77, 228-236. [CrossRef]

12. Peng, Y.; Li, J.; Si, W.; Luo, J.; Wang, Y.; Fu, J.; Li, X.; Crittenden, J.; Hao, J. Deactivation and regeneration of a commercial SCR catalyst: Comparison with alkali metals and arsenic. Appl. Catal. B Environ. 2015, 168-169, 195-202. [CrossRef]

13. Janssen, F.J.; Van den Kerkhof, F.M.; Bosch, H.; Ross, J.R. Mechanism of the reaction of nitric oxide, ammonia, and oxygen over vanadia catalysts. I. The role of oxygen studied by way of isotopic transients under dilute conditions. J. Phys. Chem. 1987, 91, 5921-5927. [CrossRef]

14. Chen, L.; Li, J.; Ge, M. The poisoning effect of alkali metals doping over nano $\mathrm{V}_{2} \mathrm{O}_{5}-\mathrm{WO}_{3} / \mathrm{TiO}_{2}$ catalysts on selective catalytic reduction of $\mathrm{NO}_{x}$ by $\mathrm{NH}_{3}$. Chem. Eng. J. 2011, 170, 531-537. [CrossRef]

15. Li, X.; Li, X.; Yang, R.T.; Mo, J.; Li, J.; Hao, J. The poisoning effects of calcium on V2O5-WO3/TiO2 catalyst for the SCR reaction: Comparison of different forms of calcium. Mol. Catal. 2017, 434, 16-24. [CrossRef]

16. Li, H.; Miao, J.; Su, Q.; Yu, Y.; Chen, Y.; Chen, J.; Wang, J. Improvement in alkali metal resistance of commercial $\mathrm{V}_{2} \mathrm{O}_{5}-\mathrm{WO}_{3} / \mathrm{TiO}_{2} \mathrm{SCR}$ catalysts modified by Ce and Cu. J. Mater. Sci. 2019, 54, 14707-14719. [CrossRef]

17. Liu, Z.; Zhang, S.; Li, J.; Zhu, J.; Ma, L. Novel $\mathrm{V}_{2} \mathrm{O}_{5}-\mathrm{CeO}_{2} / \mathrm{TiO}_{2}$ catalyst with low vanadium loading for the selective catalytic reduction of NOx by NH3. Appl. Catal. B Environ. 2014, 158-159, 11-19. [CrossRef]

18. Jin, R.; $\mathrm{Liu}, \mathrm{Y}$; $\mathrm{Wu}, \mathrm{Z}$; Wang, $\mathrm{H}$.; $\mathrm{Gu}$, T. Relationship between $\mathrm{SO}_{2}$ poisoning effects and reaction temperature for selective catalytic reduction of $\mathrm{NO}$ over $\mathrm{Mn}-\mathrm{Ce} / \mathrm{TiO}_{2}$ catalyst. Catal. Today 2010, 153, 84-89. [CrossRef]

19. Chang, H.; Li, J.; Yuan, J.; Chen, L.; Dai, Y.; Arandiyan, H.; Xu, J.; Hao, J. Ge, Mn-doped $\mathrm{CeO}_{2}-\mathrm{WO}_{3}$ catalysts for $\mathrm{NH}_{3}-\mathrm{SCR}$ of NOx: Effects of $\mathrm{SO}_{2}$ and $\mathrm{H}_{2}$ regeneration. Catal. Today 2013, 201, 139-144. [CrossRef]

20. Guo, X.; Bartholomew, C.; Hecker, W.; Baxter, L.L. Effects of sulfate species on $\mathrm{V}_{2} \mathrm{O}_{5}-\mathrm{WO}_{3} / \mathrm{TiO}_{2} \mathrm{SCR}$ catalysts in coal and biomass-fired systems. Appl. Catal. B Environ. 2009, 92, 30-40. [CrossRef]

21. Magnusson, M.; Fridell, E.; Ingelsten, H.H. The influence of sulfur dioxide and water on the performance of a marine SCR catalyst. Appl. Catal. B Environ. 2012, 111-112, 20-26. [CrossRef]

22. Ye, D.; Qu, R.; Zheng, C.; Cen, K.; Gao, X. Mechanistic investigation of enhanced reactivity of $\mathrm{NH}_{4} \mathrm{HSO}_{4}$ and $\mathrm{NO}$ on $\mathrm{Nb}$ - and Sb-doped VW/Ti SCR catalysts. Appl. Catal. A Gen. 2018, 549, 310-319. [CrossRef]

23. Hu, W.; Zhang, Y.; Liu, S.; Zheng, C.; Gao, X.; Nova, I.; Tronconi, E. Improvement in activity and alkali resistance of a novel $\mathrm{V}-\mathrm{Ce}(\mathrm{SO} 4) 2 / \mathrm{Ti}$ catalyst for selective catalytic reduction of NO with NH3. Appl. Catal. B Environ. 2017, 206, 449-460. [CrossRef]

24. López Granados, M.; Galisteo, F.C.; Lambrou, P.S.; Mariscal, R.; Sanz, J.; Sobrados, I.; Fierro, J.L.G.; Efstathiou, A.M. Role of P-containing species in phosphated $\mathrm{CeO}_{2}$ in the deterioration of its oxygen storage and release properties. J. Catal. 2006, 239, 410-421. [CrossRef]

25. Larese, C.; López Granados, M.; Mariscal, R.; Fierro, J.L.G.; Lambrou, P.S.; Efstathiou, A.M. The effect of calcination temperature on the oxygen storage and release properties of $\mathrm{CeO}_{2}$ and $\mathrm{Ce}-\mathrm{Zr}-\mathrm{O}$ metal oxides modified by phosphorus incorporation. Appl. Catal. B Environ. 2005, 59, 13-25. [CrossRef]

26. Larese, C.; Galisteo, F.C.; Granados, M.L.; Mariscal, R.; Fierro, J.L.G.; Lambrou, P.S.; Efstathiou, A.M. Effects of the $\mathrm{CePO}_{4}$ on the oxygen storage and release properties of $\mathrm{CeO}_{2}$ and $\mathrm{Ce}_{0.8} \mathrm{Zr}_{0.2} \mathrm{O}_{2}$ solid solution. J. Catal. 2004, 226, 443-456. [CrossRef]

27. Jecht, U. Flue Gas Analysis in Industry. Practical guide for Emission and Process Measurements. Testo 2004, $1-145$.

28. Zevenhoven, R.; Kilpinen, P. Control of Pollutants in Flue Gases and Fuel Gases; Helsinki University of Technology Espoo: Espoo, Finland, 2001.

29. Yang, S.; Guo, Y.; Chang, H.; Ma, L.; Peng, Y.; Qu, Z.; Yan, N.; Wang, C.; Li, J. Novel effect of SO 2 on the SCR reaction over $\mathrm{CeO}_{2}$ : Mechanism and significance. Appl. Catal. B Environ. 2013, 136, 19-28. [CrossRef]

30. Waqif, M.; Bachelier, J.; Saur, O.; Lavalley, J.-C. Acidic properties and stability of sulfate-promoted metal oxides. J. Mol. Catal. 1992, 72, 127-138. [CrossRef]

31. Saur, O.; Bensitel, M.; Saad, A.M.; Lavalley, J.; Tripp, C.P.; Morrow, B. The structure and stability of sulfated alumina and titania. J. Catal. 1986, 99, 104-110. [CrossRef]

32. Busca, G.; Saussey, H.; Saur, O.; Lavalley, J.C.; Lorenzelli, V. FT-IR characterization of the surface acidity of different titanium dioxide anatase preparations. Appl. Catal. 1985, 14, 245-260. [CrossRef]

33. Yuan, H.; He, J.; Li, R.; Ma, X. Characterization of $\mathrm{SO}_{4}{ }^{2-} / \mathrm{TiO}_{2}$ and its catalytic activity in the epoxidation reaction. Res. Chem. Intermed. 2017, 43, 4353-4368. [CrossRef] 
34. Amiridis, M.D.; Wachs, I.E.; Deo, G.; Jehng, J.-M. Reactivity of $\mathrm{V}_{2} \mathrm{O}_{5}$ catalysts for the selective catalytic

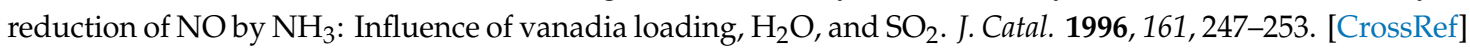

35. Jo, D.; Park, G.T.; Ryu, T.; Hong, S.B. Economical synthesis of high-silica LTA zeolites: A step forward in developing a new commercial NH3-SCR catalyst. Appl. Catal. B Environ. 2019, 243, 212-219. [CrossRef]

36. Wang, X.; Cong, Q.; Chen, L.; Shi, Y.; Shi, Y.; Li, S.; Li, W. The alkali resistance of CuNbTi catalyst for selective reduction of NO by NH3: A comparative investigation with VWTi catalyst. Appl. Catal. B Environ. 2019, 246, 166-179. [CrossRef]

37. Wang, X.; Du, X.; Zhang, L.; Yang, G.; Chen, Y.; Ran, J. Simultaneous Fast Decomposition of $\mathrm{NH}_{4} \mathrm{HSO}_{4}$ and Efficient $\mathrm{NO}_{x}$ Removal by $\mathrm{NO}_{2}$ Addition: An Option for $\mathrm{NO}_{x}$ Removal in $\mathrm{H}_{2} \mathrm{O} / \mathrm{SO}_{2}$-Contained Flue Gas at a Low Temperature. Energy Fuels 2018, 32, 6990-6994. [CrossRef]

38. Zhu, M.; Lai, J.-K.; Tumuluri, U.; Wu, Z.; Wachs, I.E. Nature of active sites and surface intermediates during SCR of $\mathrm{NO}$ with $\mathrm{NH}_{3}$ by supported $\mathrm{V}_{2} \mathrm{O}_{5}-\mathrm{WO}_{3} / \mathrm{TiO}_{2}$ catalysts. J. Am. Chem. Soc. 2017, 139, 15624-15627. [CrossRef]

39. Zhang, T.; Qu, R.; Su, W.; Li, J. A novel Ce-Ta mixed oxide catalyst for the selective catalytic reduction of $\mathrm{NO}_{x}$ with $\mathrm{NH}_{3}$. Appl. Catal. B Environ. 2015, 176, 338-346. [CrossRef]

40. Chen, L.; Li, J.; Ge, M. DRIFT Study on Cerium- Tungsten/Titiania Catalyst for Selective Catalytic Reduction of $\mathrm{NO}_{x}$ with $\mathrm{NH}_{3}$. Environ. Sci. Technol. 2010, 44, 9590-9596. [CrossRef]

41. Li, X.; Li, X.; Chen, J.; Li, J.; Hao, J. An efficient novel regeneration method for Ca-poisoning $\mathrm{V}_{2} \mathrm{O}_{5}-\mathrm{WO}_{3} / \mathrm{TiO}_{2}$ catalyst. Catal. Commun. 2016, 87, 45-48. [CrossRef]

42. Kompio, P.G.W.A.; Brückner, A.; Hipler, F.; Auer, G.; Löffler, E.; Grünert, W. A new view on the relations between tungsten and vanadium in $\mathrm{V}_{2} \mathrm{O}_{5} \mathrm{WO}_{3} / \mathrm{TiO}_{2}$ catalysts for the selective reduction of $\mathrm{NO}$ with $\mathrm{NH}_{3}$. J. Catal. 2012, 286, 237-247. [CrossRef]

43. Peng, Y.; Wang, C.; $\mathrm{Li}$, J. Structure-activity relationship of $\mathrm{VO}_{\mathrm{x}} / \mathrm{CeO}_{2}$ nanorod for $\mathrm{NO}$ removal with ammonia. Appl. Catal. B Environ. 2014, 144, 538-546. [CrossRef]

44. Ma, Z.; Wu, X.; Si, Z.; Weng, D.; Ma, J.; Xu, T. Impacts of niobia loading on active sites and surface acidity in $\mathrm{NbO}_{\mathrm{x}} / \mathrm{CeO}_{2}-\mathrm{ZrO}_{2} \mathrm{NH}_{3}-\mathrm{SCR}$ catalysts. Appl. Catal. B Environ. 2015, 179, 380-394. [CrossRef]

45. Ke, Y.; Huang, W.; Li, S.; Liao, Y.; Li, J.; Qu, Z.; Yan, N. Surface acidity enhancement of $\mathrm{CeO}_{2}$ catalysts via modification with a heteropoly acid for the selective catalytic reduction of NO with ammonia. Catal. Sci. Technol. 2019, 9, 5774-5785. [CrossRef]

46. Chen, Y.; Wang, M.; Du, X.; Ran, J.; Zhang, L.; Tang, D. High Resistance to Na Poisoning of the $\mathrm{V}_{2} \mathrm{O}_{5}-\mathrm{Ce}$ $\left(\mathrm{SO}_{4}\right)_{2} / \mathrm{TiO}_{2}$ Catalyst for the NO SCR Reaction. Aerosol Air Qual. Res. 2018, 18, 2948-2955. [CrossRef] 